\title{
A linguagem republicana em Pernambuco (1824-1835)*
}

\section{The republican language in Pernambuco (1824-1835)}

\author{
SILVIA CARLA PEREIRA DE BRITO FONSECA \\ Professora Adjunta em História do Brasil Império \\ Universidade Federal do Estado do Rio de Janeiro/UNIRIO \\ Av. Pasteur 458, Urca, Rio de Janeiro \\ silviapereirabrito@gmail.com
}

RESUMO Este artigo examina a linguagem política republicana em Pernambuco nas décadas de 1820-1830, por meio da análise da imprensa federalista que circulava na província. Sugere-se que as reflexões, bem como os argumentos, empregados em favor da federação no Império do Brasil expressaram as transformações no significado do conceito de república ao final do século XVIII.

Palavras-chave república, federação, imprensa, Pernambuco.

ABSTRACT This article examines the language of republicanism in Pernambuco in the decades of 1820/1830 through an analyses of the federalist press of the province. It sugests that the discussions, as well as the arguments, employed in favor of the federalism in the Empire of Brazil expressed the changes in the meaning of the concept of republic in the late eighteen century.

Keywords republic, federalism, press, Pernambuco

* Artigo recebido em 18/04/2011. Autor convidado. 
As Repúblicas são governos de Deus e as Monarquias governos do Diabo (...). Parece pois demonstrado, Sentinela, que de Direito, a República é governo superior e mil vezes preferiável (sic) à Monarquia. ${ }^{1}$

Desenganai-vos de que não há um só Estado livre, onde o Chefe do Poder executivo tenha o título de Rei ou Imperador (...).

Não está demasiadamente conhecido pela experiência de séculos, e vós mesmos não tendes experimentado quanto é defeituoso o Sistema de Governo que tem por Chefe um presuntivo herdeiro? (...) Onde oh (sic) filosofia? Onde oh só razão? Onde é vossa morada? Não achaste abrigo na face da terra?! Sim, lá se descobre ao Norte do Equador, vosso asilo em o novo mundo (...). Ele já domina em quase todo o Continente Americano, e segundo a Ordem da Natureza brevemente dominará o resto. ${ }^{2}$

Os estudos relativos à linguagem política republicana, ou mesmo acerca do conceito de república, a despeito de indicarem orientações teóricas distintas, sofreram profunda renovação a partir da edição e sobretudo da divulgação entre nós das obras de Quentin Skinner, John Pocock e Reinhart Koselleck.

A publicação em 1978 do livro The foundations of modern political thought, traduzido para a língua portuguesa em 1996 com o título As fundações do pensamento político moderno, contribuiu de forma decisiva para a difusão no meio acadêmico dos valores constitutivos do ideário republicano, notadamente a especificidade dos conceitos de virtude cívica e de liberdade, este último abordado na aula inaugural proferida por Skinner na Universidade de Cambridge em 1997, e editada no Brasil como Liberdade antes do Liberalismo. ${ }^{3}$

Em 1975, John Pocock publica The Machiavellian moment: Florentine political thought and the Atlantic Republican tradition, livro de grande repercussão entre os estudiosos do assunto, mas infelizmente ainda não vertido para o português, no qual tece considerações sobre a linguagem republicana e uma certa compreensão do tempo histórico. Destarte, sublinha a correlação entre o ideário republicano e uma consciência política secular no início da ldade Moderna, uma vez que recupera-se então o ideal da polis aristotélica enquanto um governo finito, localizado no tempo e no espaço. Por essa razão, um elemento vital da teoria republicana baseava-se em ideias sobre a ocorrência de eventos contingentes, nos quais o tempo era a dimensão que conferia inteligibilidade às sequências de sucessos particulares que compõem a História, constituindo-se numa forma original de historicismo. ${ }^{4}$ Por conseguinte, a contraposição de uma perspectiva temporal

Sentinella da Liberdade na sua primeira guarita, a de Pernambuco, n.35, 26 de setembro de 1835.

Desengano aos Brazileiros, n.4, 31 de julho de 1824

SKINNER, Quentin. As fundações do pensamento político moderno. São Paulo: Companhia das Letras, 1996.

SKINNER, Quentin. Liberdade antes do Liberalismo. São Paulo: Editora da Unesp, 1999.

4 POCOCK, John Greville Agard. The Machiavellian moment: Florentine political thought and the Atlantic Republican Tradition. Princeton University Press, 1975, p.3. 
e secular da História, ou seja não sagrada porque não eterna, à noção cristã correspondia ao papel desempenhado pela política, ou à capacidade dos homens de enfrentar a contingência, a fortuna, por meio da virtude cívica.

Assim sendo, a percepção de tempo associada ao Império apoiava-se em uma ordem hierárquica presente no paraíso e na natureza, cuja legitimação e categorias de organização seriam eternas, concebida a mudança apenas enquanto degeneração. Portanto, o princípio subjacente à noção de Império, e de monarquia em geral, repousava numa associação ao eterno e imutável, ao passo que ao ideário republicano correspondia um entendimento diverso do tempo, finito e humano, em vista da disjunção entre a ordem política e a ordem natural. Afirmar a república implicaria quebrar a continuidade de um universo hierárquico em momentos particulares, promovendo a particularização da História e sua secularização. ${ }^{5}$

Todavia, a singularidade das repúblicas, compreendidas como o governo dos homens sobre si, agregada à perspectiva cíclica da História, ${ }^{6}$ legatária de Políbio, importaria em sua finitude e instabilidade no tempo, e posto que a virtude era corporificada em uma forma de governo, ela compartilhava dessa contingência. Assim, a transitoriedade de um sistema de justiça humana não seria vista apenas como um aspecto da physis, a natural vida e morte das coisas, mas sim como um fracasso moral e o triunfo da Fortuna. $^{7}$

Talvez por esta razão a doutrina republicana tenha florescido na época em que as cidades livres italianas estivessem submetidas aos governos dos príncipes, ilustrando a bela assertiva de Hegel, da qual também se valera Skinner, segundo a qual "a coruja de Minerva somente abre as asas ao cair do crepúsculo". 8

Nos séculos XVI e XVII, não obstante o fortalecimento das monarquias na Europa, os argumentos da tradição humanista republicana seguiram uma linha de continuidade, cujos aspectos fundamentais seriam em boa medida apropriados pelo pensamento ilustrado do século seguinte: a crítica aos exércitos mercenários, predominando o princípio de que a república deve ter seu próprio sistema de defesa, através da prática de armar os cidadãos - base da ideia, amplamente aceita posteriormente, da milícia cidadã - o

5 POCOCK, John Greville Agard. The Machiavellian moment, p. 54.

6 "Costumam as províncias (...) nas mudanças a que são submetidas, da ordem vir à desordem, e novamente, depois, passar da desordem à ordem: porque não estando na natureza das coisas deste mundo o deter-se, quando chegam à sua máxima perfeição, não mais podendo se elevar, convém que precipitem; e de igual maneira, uma vez caídas e pelas desordens chegadas à máxima baixeza, necessariamente não podendo mais cair, convém que se elevem: assim, sempre do bem se cai no mal e do mal eleva-se ao bem". MAQUIAVEL, Nicolau. História de Florença. São Paulo: Musa Editora, 1998, p.229.

$7 \quad$ POCOCK, John Greville Agard. The Machiavellian moment, p.78. Como é conhecido, o autor sustenta, em sua alentada obra, a tese de que a experiência republicana florentina promoveu uma "comovente sociologia da liberdade", transmitida à llustração e às revoluções inglesa e americana que teriam ocorrido como "resposta" ao desafio da sobrevivência das repúblicas no tempo. Ver p.85.

8 Citado em SKINNER. Quentin. As fundações do pensamento político moderno, p.160 
estímulo à virtu enquanto compromisso com a coisa pública, bem como sua promoção por meio da educação.

No século XVIII, a conhecida tipologia das formas de governo elaborada por Montesquieu insere princípios qualitativos à classificação quantitativa de matriz aristotélica, a despeito da perpetuação da centralidade da prevalência da lei e da Constituição como atributo dos governos republicanos. Assim sendo, à distinção entre monarquia, república (aristocrática ou democrática), e despotismo - agregaram-se fatores relativos à extensão dos territórios; à igualdade ou não dos cidadãos; à origem da formulação da lei; aos "princípios" dos governos, como a honra, a virtude ou o medo.

De acordo com a temporalidade inscrita nos conceitos, observada por Reinhart Koselleck, o antigo conceito político mais amplo de respublica, compreendendo todas as formas de governo, adquire um caráter restrito de exclusividade, referido, porém, ao futuro. Por outras palavras, "um conceito utilizado histórica e teoricamente (...) saturado de experiências, se converte em um conceito de expectativa". ${ }^{.}$

$\mathrm{Na}$ segunda metade do século XVIII as antigas repúblicas, embora tivessem perdido a força política, ainda constituíam um referencial ético para a llustração, isto é, a moral republicana persistia, mas suas formas históricas pareciam decadentes. Por esse motivo, ao tomar por base as reflexões inglesas forjadas no contexto da disputa entre o rei e o parlamento no século anterior, a república se configurava num ideal que poderia existir em governos hereditários, metamorfoseada no constitucionalismo. Nesses termos, adverte Pocock que o republicanismo na Inglaterra seria qualificado mais como uma linguagem do que como um programa, de vez que tal doutrina fora formulada em decorrência da percepção da degeneração da Antiga Constituição naquele momento. ${ }^{10}$

Não surpreende que, segundo a experiência histórica inglesa, a tradição do humanismo cívico defina a república como a mistura do governo de Um, de Poucos e de Muitos, constituindo-se a combinação das distintas e não hierarquizadas virtudes na fórmula do equilíbrio político que asseguraria a sobrevivência das repúblicas em face da contingência, tendo por fim sobrepujar o tempo finito dos homens.

Dessa sorte, conforme a reflexão legatária de Aristóteles e Políbio, a perpetuação das repúblicas dependeria do equilíbrio entre os poderes. Daí a difusão do mito segundo o qual a "imortalidade" fora conjugada à República de Veneza e expressa pelo epíteto de "Sereníssima".

9 KOSELLECK, Reinhart. Futuro pasado: para una semántica de los tiempos históricos. Barcelona: Ediciones Paidós, 1979, p.354.

10 POCOCK, J. G. A. Introduction, Oceana: its ideological context. In: The political works of James Harrington. Cambridge: Cambridge University Press, 1977, p.15. 
Também o conceito de federalismo, ao final do século XVIII, alcança um sentido mais complexo referenciado pelas vicissitudes da Revolução Americana. Assim, à ideia de federação, anteriormente compreendida como sinônimo de confederação - usualmente associada a acordos provisórios de natureza militar ou comercial entre Estados autônomos - sucede a construção de um significado, historicamente determinado, com base na assimilação ao conceito de república, este da mesma forma revisto em seus princípios, fundamentados até então na tradição das repúblicas europeias antigas e modernas.

Por outras palavras, o debate norte-americano nas décadas de 1770 e 1780, no contexto da ratificação da Constituição, presente nos Artigos federalistas, permite entrever de que maneira o deslocamento semântico e o entrelaçamento de ambos os conceitos revelaram não apenas uma nova concepção de tempo, mas notadamente a composição da base de sustentação das instituições políticas no Novo Mundo, tendo em vista a construção do conceito de América. ${ }^{11}$

Assim sendo, a reinvenção da república, como se sabe, resultado de rumoroso embate entre a linguagem republicana clássica e o pensamento liberal, permitiu transformar a Constituição no símbolo da unidade nacional em meio à diversidade regional, étnica, cultural e religiosa.

Para tanto, cabe mencionar em primeiro lugar a inversão semântica da palavra "federalista" que na década de 1770 designava aqueles defensores da consolidação do poder local contra os "nacionalistas", ou seja, os que pugnavam por um governo central com amplas atribuições. Em segundo lugar a redefinição da República, associada, à época, à tradição europeia e, em grande medida inglesa, do governo misto, com a qual procurava-se romper especialmente em virtude da ausência de aristocracia hereditária na América. Por outro lado, a ideia de república compreenderia historicamente a adequação restrita a pequenos territórios, a relativa homogeneidade da população, além da virtude cívica como princípio constitutivo do governo. Não obstante, à inflexão semântica do conceito de república correspondeu a presunção de aperfeiçoamento e adaptação do ideário subjacente às condições do Novo Mundo, criando-se a noção de república federada.

No entanto, a leitura de O Espírito das leis parece refletir que o conflito entre monarquias e repúblicas constituiu-se no mote para as reflexões de Montesquieu acerca dos princípios distintivos das diversas formas de governo, considerações estas que marcariam profundamente tanto os fundadores da "República imperial" norte-americana, quanto as elites política e intelectual do Império do Brasil.

11 Para uma análise desta argumentação ver FONSECA, Silvia C. P. Brito. A América como um conceito: contribuição para o estudo da imprensa republicana fluminense e pernambucana entre 1829 e 1832. Cadernos do CHDD, Brasília, Número Especial, 2005. 
Este artigo examina a compreensão do conceito de república em Pernambuco nas décadas de 1820 e 1830. O texto se divide em seis partes, enfatizando os escritos políticos de frei Caneca e Antonio Borges da Fonseca, os jornais doutrinários que divulgavam as atividades políticas da Sociedade Federal de Pernambuco, assim como os relatos a respeito da chamada República de Afogados, revolta ocorrida em 1829 na cidade de Santo Antão, a qual se atribuía, à época, o propósito de proclamar um governo republicano.

Para tanto, optou-se por tomar como fonte histórica a imprensa doutrinária pernambucana, considerando-se como tal alguns jornais que circularam em Recife no período, ainda que boa parte dos seus redatores não fosse natural de Pernambuco, mas cidadãos desta província "por escolha", de acordo com o registro que frei Caneca imprime aos conceitos de pátria e de cidadania.

Como é conhecido, em sua justamente célebre Dissertação sobre o que se deve entender por pátria do cidadão e deveres deste para com a mesma pátria, ${ }^{12}$ o frade pernambucano amparou-se em Cícero para dar preferência à "pátria de direito" em detrimento da "pátria de lugar", porquanto aquela adviria da escolha, ou seja, da razão que particulariza a humanidade, não sendo fruto de mero acaso. Por suas palavras: "O lugar em que nascemos é pátria forçada; e aquele de que somos cidadãos é pátria forçosa". ${ }^{13}$

Nessa circunstância estão o português João Soares Lisboa, redator do jornal fluminense Correio do Rio de Janeiro, que circulou entre os anos de 1822 e 1823 na Corte, como também do bem menos conhecido Desengano aos brazileiros, editado em Recife no ano seguinte; o legendário baiano Cipriano José Barata de Almeida, autor das célebres Sentinelas da Liberdade, dentre as quais a Sentinella da liberdade na guarita de Pernambuco, publicada ao longo do ano de 1823 em Recife; e o paraibano Antonio Borges da Fonseca, redator da folha Abelha pernambucana, escrita em Recife em 1829, além do famoso periódico O republico, que conheceu ao menos seis diferentes fases entre os anos de 1831 e 1855, editado no Rio de Janeiro, Paraíba e Recife. ${ }^{14}$ Todos tomaram Pernambuco por pátria seja no início e/ou no fim de suas vidas.

12 MELLO, Antônio Joaquim de. (org.) Obras políticas e literárias de frei Joaquim do Amor Divino Caneca. Recife: Tipografia Mercantil do Recife, 1875, p.181-221. Edição fac-símile de 1973.

13 MELLO, Antônio Joaquim de. (org.) Obras políticas e literárias, 1875, p.203.

14 Borges da Fonseca parece ter sido o redator que redigiu o maior número de periódicos ao longo de seus 64 anos de vida. Segundo Mário Santos teriam sido 23 jornais em 42 anos, SANTOS, Mario Almeida. Um homem contra o império: Antonio Borges da Fonseca. João Pessoa: União, 1994, p.15. Velho Sobrinho relacionou 21 folhas: A tesoura, Pernambuco, Tipografia do Diário, 1828; Gazeta paraibana, 1828-1829; Abelha pernambucana, Pernambuco, 1829-1830; O republico, Rio de Janeiro, 1831; O republico, Paraíba, 1832; O republico extraordinario, Pernambuco, 1832 (3 nos, 13, 22 e 27 de outubro); O republico, Rio de Janeiro, 1834; O republico, Rio de Janeiro, 1837 (nova numeração); O republico, Rio de Janeiro, 1853-1855; O publicador paraibano, Paraíba, 
Inicialmente é preciso lembrar que aqueles que pretenderam reconstituir o relevo de Pernambuco, no contexto dos conflitos políticos da década de 1820 apoiavam-se na nostalgia de um passado destemido e venturoso, ao recuperar o tempo dos flamengos. Assim, empregavam a cronologia da história local como elemento explicativo e determinante na relação entre o passado e o futuro, como também enalteciam a reconquista do território pernambucano à custa de seu sangue, vidas e fazendas, experiência esta identificada como fundadora da identidade provincial e constitutiva de poderoso imaginário nativista na província. ${ }^{15}$

Outra peculiaridade, em certa medida relacionada à gênese da "nobreza da terra" no século XVIII, bem como à própria memória histórica do período holandês, diz respeito à tão recorrente quanto polêmica associação entre as manifestações republicanas em Pernambuco e uma possível herança da ocupação batava.

Nesta direção caminham alguns depoimentos de viajantes que visitaram a província na primeira metade do século XIX, em meio aos conflitos de 1817 e 1824. Conforme assinalou a inglesa Maria Graham (1785-1842) em seu Diário de uma viagem ao Brasil, a origem e as razões do movimento de 1817 estariam vinculadas a uma certa tradição "democrática" e combativa da antiga capitania.

O povo do Recife, e de suas vizinhanças havia-se embebido de algumas noções de governo democrático através de seus antigos dominadores holandeses (...). Estavam aborrecidos com o pagamento das taxas e contribuições das quais nunca se haviam beneficiado e que só serviam para enriquecer os favoritos da Corte (...). O exemplo dos americanos espanhóis teve sem dúvida sua importância. ${ }^{16}$

Mais céticos, entretanto, se revelaram os comentários de Spix e Martius, impedidos de visitar o Recife devido à eclosão do movimento de 1817. Além de alguns dados demográficos sobre a capitania e considerações sobre a criação do Seminário de Olinda, avaliavam os "muitos exemplos de perturbações civis, que se devem atribuir não tanto à ilustração e instrução científica (...) quanto a reivindicações presunçosas de certas famílias ricas e

1833; O publicador paraibano, Pernambuco, 1833 (16 números, entre 9 de maio e 24 de novembro); Correio do norte, Pernambuco, 1841-1842, Tipografia de Luis Ignacio Ribeiro Roma; O nazareno, Pernambuco, 1843-1848, Tipografia Social Nazarena de Antonio Borges da Fonseca (números 1-54); O foguete, Pernambuco, 1844; O verdadeiro regenerador, Pernambuco, 1844-1845; O espelho, Pernambuco, 1845; O verdadeiro, Pernambuco, 1845; O eleitor, Recife, 1846; O tribuno, Recife, 1847-1848; A mentira, Pernambuco, 1848; Advogado do povo, Pernambuco, 1848; O constituinte, Pernambuco, 1861. VELHO SOBRINHO, João Francisco. Dicionário biobibliográfico brasileiro. Rio de Janeiro: Irmãos Pongetti, 2 vs, 1937, p.403. O autor omite a terceira fase de 0 republico, de 1834. Helio Vianna cita ainda A revolução de Novembro, Recife, 1852; O Prometeu, Paraíba, 1856; O tribuno, Recife, 1866-1867 (segunda fase); O tribuno, Recife, 1869, (terceira fase). VIANNA, Hélio. Contribuição à história da imprensa brasileira (1812-1869). Rio de Janeiro: Imprensa Nacional, 1945, p.535-595.

15 MELLO, Evaldo Cabral de. Rubro veio: o imaginário da restauração pernambucana. Rio de Janeiro: Nova Fronteira, 1986.

16 GRAHAM, Maria. Diário de uma viagem ao Brasil e de uma estada nesse país durante parte dos anos de 1821, 1822 e 1823. São Paulo: Cia Editora Nacional, 1956, p.64. 
influentes que se atribuem grandes méritos na libertação do Brasil do jugo dos holandeses, o que se deve julgar inconsiderada manifestação de ideias mal entendidas". ${ }^{17}$ John Armitage, por seu turno, ao indagar as "origens" da Confederação do Equador, asseverava que, desde a Restauração, os pernambucanos se haviam caracterizado por seu "espírito turbulento e democrático". ${ }^{18}$

Em instigante artigo, Evaldo Cabral de Mello postula que o republicanismo holandês não se fundira ao nativismo pernambucano, visto que ao tempo da Guerra dos Mascates a proposta de instauração de uma república remetia-se ao modelo veneziano, sendo esta "a única encarnação conhecida na América portuguesa do que se designou por 'mito de Veneza'". ${ }^{19}$

Por outro lado, convém sublinhar a importância de que se reveste a obra de Robert Southey. Publicada em 1810, mas apenas traduzida na segunda metade do século, teria provavelmente influenciado a redação do panfleto do visconde de Cairú, Apello a honra brasileira contra a facção dos federalistas de Pernambuco, editado em 1824, no qual identificava as "três revoluções dos anarquistas" pernambucanos em pouco mais de um século: "A primeira foi em 1710 (...); a segunda foi em 1817 (...); a terceira é a que neste ano rebentou na mesma praça". ${ }^{20}$

Todavia, Cabral de Mello adverte que os movimentos políticos em Pernambuco na primeira metade do século XIX tributavam uma profunda antipatia à experiência holandesa, assim como às suas instituições. Para tanto contribuiria a ortodoxia católica, obstando o enaltecimento de uma nação protestante, mas, acima de tudo, a sobrevivência entre a população do nativismo de viés conservador que arrogava à restauração a prova de fidelidade ao monarquismo pelos pernambucanos. ${ }^{21}$

Não obstante, o elogio à ocupação holandesa teria por desdobramento o reconhecimento de uma singularização em relação às demais províncias, acentuada pela forte identidade regional. Além disso, tomando por base 0 imaginário nativista, presente em cada fonte, a restauração no século XVII significaria o primeiro episódio de uma tradição revolucionária que viria a conferir um "sentido" ou uma linha de continuidade e coerência a movimentos políticos ocorridos em contextos históricos distintos que, por sua vez, pouco ou nada teriam em comum. "Expulsão dos batavos, Guerra dos Mascates, revolução de 1817 e Confederação do Equador correspondiam a momentos diferentes de um mesmo passado solidário; exprimir uma re-

17 SPIX, J. B. von e MARTIUS, Karl Friedrich Phillip von. Viagem pelo Brasil (1817-1820). São Paulo: Melhoramentos, 1961, v.ll, p.269.

18 ARMITAGE, J. História do Brasil. São Paulo: Melhoramentos, 1972, p.79.

19 MELLO, Evaldo Cabral de. O mito de Veneza no Brasil. In: Um imenso Portugal: história e historiografia. São Paulo: Editora 34, 2002, p.156.

20 LISBOA, Jose da Silva. Apello a honra brasileira contra a facção dos federalistas de Pernambuco. Rio de Janeiro: Tipografia Nacional, 1824, p.33 e ss.

21 MELLO, Evaldo Cabral de. O mito de Veneza no Brasil, p.156. 
serva no tocante a qualquer deles, sobretudo ao acontecimento fundador, equivalia a pôr todos em tela de juízo". ${ }^{22}$

Nas primeiras décadas do século XIX o sentimento de se viver um "novo" tempo por certo tem origem nas apropriações do pensamento ilustrado do século anterior, assim como nas repercussões, necessariamente mediadas, das revoluções na América do Norte e na França contra o que seria denominado "despotismo" ou "absolutismo". No mundo luso-brasileiro, as novas formas de organização do Estado, expressas pelo pacto constitucional, promoveram o subsequente deslizamento do conceito de soberania do monarca para a nação, representada nas Cortes.

À expansão dos princípios ilustrados no século XVIII, corresponderia uma inflexão no imaginário político a partir da correlata valorização do indivíduo como principal referência filosófica, política e econômica. Igualmente, a extensão de novas formas de sociabilidade, por meio da multiplicação dos salões, academias e lojas maçônicas, teria originado concepções mais igualitárias, bem como a opinião pública.

Convém observar que em estreita relação com a percepção de ruptura, o discurso republicano revelava então a esperança de um "novo" tempo, impulsionado pela reação pernambucana à dissolução da Constituinte em 1823, mas sobretudo pela abdicação do imperador em 1831. Deve-se lembrar que, após a Revolução do Porto, particularmente a partir de 1822, gradativamente se desfaz o senso de pertencimento à nação portuguesa contrapondo-se a este a ideia de "nação" americana, ainda que plural, referenciada pela "juventude" do novo continente.

Portanto, principalmente no que pertence a Pernambuco, torna-se possível perceber a polarização de um contexto ainda marcado pela imposição dos princípios da Santa Aliança, o que permite ampliar a influição dos escritos de Thomas Paine, incorporando as noções de pátria e país a um conjunto mais vasto, informado pela positivação da diversidade étnica, religiosa e geográfica, conformada na utopia do Novo Mundo.

\section{Frei Caneca: entre os antigos e os modernos}

Com base no deslocamento do conceito de soberania para as Cortes representativas, assim como na defesa dos princípios federalistas, procurase compreender as considerações de frei Caneca presentes em seus textos doutrinários escritos à época da instalação da Constituinte no Rio de Janeiro a partir de maio de 1823.

22 MELLO, Evaldo. O rubro veio, p.378. Sobre o assunto, ver também FONSECA, Silvia Carla Pereira de Brito. História e memória: os relatos da Confederação do Equador (1824-1924). Revista Maracanan. Revista do Programa de Pós-Graduação em História da Universidade do Estado do Rio de Janeiro, 2007. 
Conforme essa visão, o ideário republicano, traduzido no federalismo, permitiria que a coexistência da diversidade fosse assegurada por meio da autonomia conferida, assim se esperava, pelo pacto constitucional. Assim é possível perceber dois elementos distintos e dissociados após a independência. "Nós estamos, sim, independentes mas não constituídos. (...) O Brasil, só pelo fato de sua separação de Portugal e proclamação da sua independência, ficou de fato independente, não só no todo como em cada uma de suas partes ou províncias; e estas, independentes umas das outras. Ficou o Brasil soberano, não só no todo, como em cada uma das suas províncias". ${ }^{23}$

A República assume, por essa via, não apenas o meio pelo qual se pretendia garantir autonomia e liberdade, mas expressa, sobretudo a reação ao desengano constitucional. "Não há pessoa letrada que não conheça este perigo (...) Sem representação nacional, sem cortes soberanas que elas mesmas formem a nossa Constituição, não há império. Debaixo desta condição impreterível é que aclamamos a s.m. e s.m. o jurou também da sua parte. Se por vossas tramas s. m. faltar ao seu dever, e não celebrar já e já as cortes soberanas, está dissolvido o pacto". ${ }^{24}$

Como é conhecido, frei Caneca tomou parte em inúmeras e calorosas polêmicas na imprensa ao longo de sua curta vida. Em resposta à carta de frei Sampaio, ex-redator do periódico Regulador brasileiro, ao deputado Joaquim Carneiro da Cunha, publicada no Diario do governo do Rio de Janeiro, Caneca contesta as proposições do frade, tidas pelo deputado como coadjuvantes dos distúrbios que levaram à deposição da Junta de Governo de Gervásio Pires Ferreira no ano anterior.

Inicialmente ocupa-se do pressuposto da doutrina que pretende impugnar, qual seja, a reivindicação de que a Constituição deveria se acomodar às circunstâncias morais dos povos e ao sistema da sua educação política, ancorando-se no passado.

Estas circunstâncias morais dos povos, e sistema da sua educação política relativamente ao Brasil, ou se podem entender das atuais do Brasil, ou das futuras, que ele pode ter; (...) o sistema da nossa educação política, desde a povoação do Brasil até agora, há sido o sistema do servilismo, da escravidão, do governo absoluto, despótico e tirânico; logo, devendo acomodar-se a este sistema a nossa Constituição, o que é que prega vossa mercê?

O que planta com essa doutrina?

Para que coisa previne os povos?

23 CANECA, Frei. Typhis pernambucano, n.XXI, 10 de junho de 1824. Apud: MELLO, Evaldo Cabral de. (org.) Frei Joaquim do Amor Divino Caneca. São Paulo: Editora 34, 2001 p.463-464.

24 CANECA, Frei. Typhis pernambucano, n.VI, 29 de janeiro de 1824. Apud: MELLO, Evaldo Cabral de. (org.) Frei Joaquim do Amor Divino Caneca, p.344-345. 
Que tema dá aos representantes da nação?

Parece-me que os mais idiotas responderão - o despotismo. ${ }^{25}$

Efetivamente, a controvérsia tinha por objetivo chamar a atenção para quatro temas correlatos que seriam alvo de acirrado debate na Constituinte: em primeiro lugar o direito de veto do imperador às leis propostas pelo Legislativo; em segundo lugar a extensão da faculdade legislativa ao Executivo; em terceiro lugar o controle das Forças Armadas pelo Imperador; em quarto lugar a instituição de uma Câmara alta, sua composição e atribuições. Portanto, não tomar a experiência como referência, "fonte caudal das nossas inquietações, perigos e desgraças", significava acentuar a especificidade de um tempo definido pelo pacto constitucional, marco inicial da existência política.

\begin{abstract}
Os publicistas todos têm falado de monarquias já constituídas debaixo de certos sistemas (...) onde tudo estando já feito, só se tratava de fazer simplesmente algumas reformas mais urgentes; outras são monarquias, como a inglesa, onde há um freio para o abuso desse veto, e um contrapeso à sua preponderância. Nós porém estamos fora destas circunstâncias; em nós nada se acha feito; agora é que começamos a constituir-nos; a nossa existência política principiou no dia 3 de maio. ${ }^{26}$
\end{abstract}

Dando continuidade ao jogo de associações, conclui que "é inegável que, por isso que declaramos a nossa independência e separação de Portugal, estamos no caso dos anglo-americanos", ${ }^{27}$ e valendo-se da autoridade do deputado Antonio Carlos de Andrada, que teria sido interpelado acerca da "forma de governo própria do Brasil", retoma a proposta de que este deveria talvez só "adotar um governo federal, pouco mais ou menos como o dos Estados Unidos da América; por ser uma nação assaz nova; por não ter propriamente classes; porque a sua nobreza não passa de uma pueril vaidade de indivíduos que não formam corpo; porque o seu clero é de nenhuma monta, pela falta de riquezas e luzes; e muito principalmente atendendo-se a que o Brasil não faz propriamente uma nação, mas quase tantas quantas as províncias, distintas em caráter peculiar, e sempre inimigas e rivais". ${ }^{28}$

Após a deflagração da Confederação do Equador, ao rechaçar a proclamação do Imperador que clamava aos pernambucanos pelo abandono de

25 CANECA, Frei. Carta de Pítia a Damão, n.IV. Apud: MELLO, Evaldo Cabral de. (org.) Frei Joaquim do Amor Divino Caneca, p.212. Grifo no original.

26 CANECA, Frei. Carta de Pítia a Damão, n.IV. In: Apud: MELLO, Evaldo Cabral de. (org.) Frei Joaquim do Amor Divino Caneca, p.215-216. Grifo no original.

27 CANECA, Frei. Carta de Pítia a Damão, n. IV. Apud: MELLO, Evaldo Cabral de. (org.) Frei Joaquim do Amor Divino Caneca, p.216.

28 CANECA, Frei, Carta de Pítia a Damão, n.IV. Apud: MELLO, Evaldo Cabral de. (org.) Frei Joaquim do Amor Divino Caneca. Grifo no original. 
"sistemas políticos reprovados pelas lições da experiência, absolutamente incompatíveis com a vossa atual situação", ${ }^{29}$ frei Caneca imputava à conduta do imperador a eclosão do movimento.

É inegável que em todo o Brasil existe uma bem visível fermentação para se mudar a forma do governo, e que talvez não esteja muito arredado de nós o momento em que se veja tremular em todo o Brasil outros pavilhões diferentes dos atuais Luso-Brasileiro, e que esta mudança trará consigo a conseqüência infalível de s. m. se retirar para sua pátria natural, e perder o amor escrito que tem a adotiva. (...)

O Brasil tinha e tem todas as proporções para formar um estado federativo. A grandeza do seu território, as diversíssimas riquezas do seu solo, os diversos caracteres dos povos que o habitam (...) a simplicidade de seus costumes, que os habilitam para a prática das virtudes republicanas, a falta das classes salientes da nobreza europeia, a impotência do seu clero, o gênio da liberdade, que presidiu na formação desses povos pelos seus antepassados europeus e indígenas, a sua localidade entre governos republicanos, e demais a mais a desoladora e vergonhosa escravidão, em que se acham por três séculos, tudo isto cooperava para que lançando fora o jugo português, aborrecessem aos Brasileiros para sempre testas coroadas, e procurassem um governo o mais livre possível. ${ }^{30}$

Nesta citação é possível perceber a evocação de inúmeros argumentos para a instauração da República no Brasil que revelam uma curiosa combinação entre os parâmetros das repúblicas antigas e modernas, hibridismo este que determinaria a especificidade do período. Em primeiro lugar, ao citar a extensão do território e a diversidade de seus habitantes como aspectos favoráveis ao governo republicano, deixa claro que sua referência histórica é a república federativa, tal como fora teorizada pelos federalistas norte-americanos.

Em segundo lugar, por outro lado, frei Caneca recupera o ideal de virtude cívica, tema aliás central em seus escritos, fundamentado na analogia entre corpo civil e corpo político e expresso na recusa ao luxo e à riqueza, vistos como fatores de corrupção, conforme a tradição da linguagem republicana clássica. Em terceiro lugar, a referida ausência de aristocracia hereditária e a suposta fragilidade do clero remetem mais uma vez para a particularidade das repúblicas americanas, assim como a "imposição geográfica" ou a "localidade entre governos republicanos". Em quarto lugar, o argumento que articula o passado, construído com base na ideia de que a liberdade teria presidido a formação dos povos no Brasil, e o futuro a ser moldado a partir da noção de ruptura com a "desoladora e vergonhosa escravidão", justificando assim o distanciamento da monarquia. A defesa da República

29 Typhis pernambucano, n.XV, 8 de julho de 1824 Apud: MELLO, Evaldo Cabral de. (org.) Frei Joaquim do Amor Divino Caneca, p.499.

30 Typhis pernambucano, n.XXV, 8 de julho de 1824. Apud: MELLO, Evaldo Cabral de. (org.) Frei Joaquim do Amor Divino Caneca, p.501-502. Grifo no original. 
assume, por essa via, uma legitimidade histórica, adquirindo o passado e o futuro uma força imanente ao decurso do tempo.

A propósito da polêmica em torno dos temas centrais na Constituinte, anteriormente assinalados, ou a constituição do "império do Brasil pelo Almanaque da Turquia", ${ }^{31}$ o frade carmelita recobra a visão de uma Câmara alta não como um corpo político intermediário que visasse limitar o poder do imperador, mas sim como uma fonte de males e iniquidades. "Para que havemos de pôr-nos na precisão de criar uma nobreza, e passarmos pelos incômodos que ela costuma em toda parte do mundo trazer à humanidade?"32

Talvez seja lícito supor que a linguagem do republicanismo também se revele, em que pesem as diversas apropriações liberais, nas críticas à existência de um exército permanente. "Para que o poder Executivo não oprima a nação, é necessário que as tropas que se lhe confiam sejam o povo e tenham o espírito do povo (...) é necessário, ou que o Exército não seja permanente, ou (...) que eles habitem com os demais cidadãos, que não tenham campo separado, nem quartéis, nem praça de guerra. Fora desta circunstância, a Força Armada sempre foi o instrumento da tirania". ${ }^{33}$

Ao rebater a postulação do ex-redator do Regulador brasileiro, segundo a qual o "império do Brasil 'deve ser uma monarquia verdadeiramente constitucional, segundo o espírito político da Europa'", Caneca apropria-se das assertivas do abade Raynal, delineando a especificidade local e o passado à luz do nativismo pernambucano.

\section{Então o Brasil é Europa?}

O clima do Brasil, a sua posição geográfica, a extensão do seu território, o caráter moral de seus povos, seus costumes (...).

O espírito da Europa é o espírito do servilismo e da escravidão que se tem mostrado por infinitas vezes em todos os Estados europeus, e agora em Portugal, Espanha e França, a despeito de poucos indivíduos verdadeiramente liberais. Os brasileiros, descendemos dos primeiros indígenas deste continente, e dos europeus transplantados nele. Dos primeiros, diz o historiador: 'As ideias de dependência e de submissão (...) são incógnitas a estes povos ateus' (...). É disto uma prova a grandíssima dificuldade que encontrou na Bahia de Todos os Santos Tomé de Souza, depois de 1549, em sujeitar à ordem homens que haviam sempre vivido na anarquia; a vida independente em que sempre estiveram os paulistas até o ano de 1717; a restauração de Pernambuco do jugo holandês. ${ }^{34}$

31 CANECA, Frei. Carta de Pítia a Damão, n.IV. Apud: MELLO, Evaldo Cabral de. (org.) Frei Joaquim do Amor Divino Caneca, p.219

32 CANECA, Frei. Carta de Pítia a Damão, n.V. Apud: MELLO, Evaldo Cabral de. (org.) Frei Joaquim do Amor Divino Caneca, p.226.

33 CANECA, Frei. Carta de Pítia a Damão, n.V. Apud: MELLO, Evaldo Cabral de. (org.) Frei Joaquim do Amor Divino Caneca, p.227.

34 CANECA, Frei. Carta de Pítia a Damão, n.V. Apud: MELLO, Evaldo Cabral de. (org.) Frei Joaquim do Amor Divino Caneca, p.228-229. 
Na década de 1820, especialmente após a edição do que seria batizado de Doutrina Monroe, cuja expressão política na época era bastante diversa daquela que seria atribuída posteriormente, a ideia de uma "nação americana" exprimia um sentimento de oposição a Portugal, assim como a possibilidade de autonomia e federalismo. O Typhis pernambucano imprimiu em fevereiro de 1824.

Washington, 2 de dezembro de 1823.

Abrindo-se nesta cidade o Congresso para a nova legislatura, James Monroe, presidente daquela república, dirigiu às Câmaras do Congresso, imediatamente depois da sua abertura, uma eloqüentíssima mensagem, da qual extraímos as seguintes passagens, por estarem em relação com os nossos negócios. (...)

Nós somos por necessidade mais proximamente interessados nos sucessos deste hemisfério (americano) e isto por motivos bem conhecidos ao observador judicioso e imparcial. O sistema político das potências aliadas (europeias) é absolutamente diferente do sistema da América. Esta diferença provém da que existe em seus respectivos governos (...). Nós devemos, entretanto, em obséquio à franqueza da boa inteligência que reina entre os Estados Unidos e aquelas potências, declarar que nós consideramos qualquer atentado da sua parte, para estender este sistema (europeu) a alguma parte deste hemisfério como perigoso à nossa paz e segurança. ${ }^{35}$

Para os aspectos que interessam aqui, seria também oportuno ressaltar a centralidade do conceito de liberdade civil no discurso político e, de forma inseparável, na trajetória do frade carmelita desdobrando-se em suas considerações acerca da virtude e da corrupção na vida pública.

Conforme lembra Quentin Skinner em sua análise a respeito do papel dos teóricos na política do Estado, os humanistas do norte desenvolvem um debate, inserido na questão do aconselhamento a reis e príncipes, acerca dos méritos opostos da vida ativa e da vida contemplativa, ou como prefere chamar, do otium e do negotium - "uma vida de quietude e contemplação, contraposta à atividade dos negócios públicos". ${ }^{36} \mathrm{Em}$ seu estudo sobre a Utopia, Skinner reflete a propósito do uso feito por Thomas Morus desses dois termos que constituem princípios classificatórios do pensamento político moderno. Por um lado, a possibilidade do cidadão procurar a felicidade pessoal; por outro lado, a participação ativa nos assuntos do Estado, na qual todo louvor à virtude deriva da ação. ${ }^{37}$

35 Typhis pernambucano, n.IX, 26 de fevereiro de 1824. Apud: MELLO, Evaldo Cabral de. (org.) Frei Joaquim do Amor Divino Caneca, p.373-374. Grifo no original.

36 SKINNER, Quentin. As fundações do pensamento político moderno, p.236.

37 "Essa dicotomia era associada à clássica distinção entre monarquias e repúblicas. Para a vida do otium (...) acreditava-se apenas ser possível numa sociedade, cujos assuntos do Estado fossem confiados a um único, forte e justo soberano, o pater patrie, cujo papel seria assumir as obrigações da vita activa, deixando todos os outros livres para buscarem seus objetivos pessoais. A vida do negotium, por outro lado, seria apenas possível quando todo o corpo de cidadãos estivesse apto a se engajar na ativa vida política e quando cada um visse sua felicidade como constituída por esse engajamento. Era também claro que, na prática, a vida do otium só 
É possível entrever em diversas passagens dos escritos políticos de frei Caneca semelhante reflexão. No Itinerário, escrito em 1824, no qual narra a retirada em direção ao Ceará, em decorrência da ocupação de Recife pelas tropas imperiais, o frade carmelita lembra que teria sido perseguido por derivar sua sorte da pátria pernambucana.

Vivíamos em descanso em nossa pátria, a cidade do Recife de Pernambuco, trabalhando na educação literária da mocidade, regendo três anos a cadeira nacional de geometria elementar, na qual empregávamos todos os nossos desvelos, para deixarmos à posteridade justa razão de terem saudades dos nossos dias; quando as mudanças políticas do Brasil nos penhoraram para que ajudássemos nossos compatriotas. (...) Assim tivemos por meio da imprensa de comunicar nossos pensamentos em diversos escritos. (...) À proporção que nossos trabalhos se estendiam a beneficiar nossos compatriotas, nós caminhávamos ao perigo e à ruína, pois que nossas verdades chocavam os interesses de d. Pedro de Alcântara, príncipe português, que o Brasil imprudente e loucamente havia aclamado seu imperador. (...) Mas para nossa glória gostamos do encantador néctar da liberdade, e nós votamos no seu altar não vacilarmos um só instante (...) e julgamos indigno do caráter dum patriota arrepiar a carreira que tem encetado em serviço da cara mãe pátria, a nossa mesma sorte. ${ }^{38}$

Todavia, dois anos antes, na anteriormente citada Dissertação sobre o que se deve entender por pátria do cidadão e deveres deste para com a mesma pátria, frei Caneca já havia abordado o tema na parte IV, intitulada "os ofícios do cidadão". Nesta passagem, inteiramente inspirada em Cícero e Tito Lívio, ressaltara não apenas a primazia do bem público em detrimento do "cômodo particular", mas sobretudo a imposição cívica de se abrir mão da própria existência, assim como das vidas dos filhos, se assim o exigisse o bem da pátria.

Convém observar a relevância do conceito de virtude cívica, tal como fora teorizado pelos republicanos, na argumentação do frade pernambucano: "Não tem mais preço o sangue e vida dos filhos na estima de um virtuoso pai patriota, se se trata do bem da república". Remete-se então a Lívio: "O cidadão virtuoso tem a república em maior preço do que os parentescos particulares". Quanto à conservação da própria vida, vista como o primeiro dever do homem, "esta mesma vida ele a deve sacrificar à conservação e bem da república; e é desta maneira que ele se faz caro à pátria, e credor da imortalidade". ${ }^{39}$

poderia se realizar sob uma monarquia, e que o negotium, apenas sob a república". PAGDEN, Anthony. (org.) The languages of political theory in early-Modern Europe. Cambridge: Cambridge University Press, 1990, p.7.

38 Itinerário que fez frei Joaquim do Amor Divino Caneca, saindo de Pernambuco a 16 de setembro de 1824, para a província do Ceará Grande. Publicado em MELLO, Evaldo Cabral de. (org.) Frei Joaquim do Amor Divino Caneca, p.570.

39 Dissertação sobre o que se deve entender por pátria do cidadão. Apud: MELLO, Evaldo Cabral de. (org.) Frei Joaquim do Amor Divino Caneca, p.89-90. República comporta aqui o sentido de território. 
Na Carta de Pítia a Damão número VII, frei Caneca enceta polêmica com o redator do Conciliador nacional, quando traça um paralelo "entre o presidente dos Estados Unidos na América e um rei constitucional”. Tal comparação visava repudiar o controle das Forças Armadas pelo imperador e associar a brevidade das legislaturas aos governos livres. ${ }^{40}$

O presidente dos Estados Unidos é eletivo, mas não vitalício, como o Zumbi da república dos Palmares, na província de Alagoas; (...). O imperador é hereditário, e o seu poder, eterno na sua descendência, quando o presidente dos Estados Unidos não passa o acanhado termo de três anos. Os Estados Unidos são uma federação de muitas repúblicas, independentes umas das outras, ao mesmo passo que o Brasil é uma monarquia (...).

O governo trienal do presidente dos Estados Unidos Ihe tira a ocasião de abusar da Força Armada para escravizar a nação, pois que não pode planizar, efetuar o projeto e desfrutar os resultados (...) contra tantos povos espalhados por tão vastos territórios, e tão práticos na liberdade (...). Está dentro da máxima fundamental da política (...) que em toda magistratura a grandeza do poder deve de ser compensada pela brevidade da sua duração. ${ }^{41}$

Além do elogio ao governo temporário, frei Caneca, guiado por Montesquieu, hierarquiza e opõe os princípios distintivos das formas de governo, na medida em que nas monarquias a dependência pessoal ensejaria a corrupção. "Ao mesmo tempo que a virtude, princípio fundamental das repúblicas, faz com que na federação os diversos estados confederados se oponham aos projetos do opressor, a honra nas monarquias apresenta aos monarcas infinitos braços, que o sustentem no despotismo e tirania; pois que este é o meio mais fácil de se conseguirem as distinções e preferências, único alvo da honra (...). Daqui também se segue que quem prega uma tal doutrina segue partido que não é o da grande causa do Brasil, e que nos quer introduzir à cunha os costumes e legislação inglesa" ${ }^{42}$ conclui, refutando a tradição do governo misto na América.

\section{O ideário republicano de Borges da Fonseca}

Como se pode inferir a partir da leitura das fontes, tais alusões indicam a proeminência que à época possuía o que se pode chamar de paradigma ou retórica americana. Heloísa Starling e Christian Lynch chamam a atenção para tal correspondência na cultura política de então: "Se, por um lado, havia uma clara associação entre conceitos como monarquia, governo misto,

40 CANECA, Frei. Carta da Pítia a Damão, n.VI. Apud: MELLO, Evaldo Cabral de. (org.) Frei Joaquim do Amor Divino Caneca, p.253. Grifo no original.

41 CANECA, Frei. Carta da Pítia a Damão, n.VII. Apud: MELLO, Evaldo Cabral de. (org.) Frei Joaquim do Amor Divino Caneca, p.256-257. Grifo no original.

42 CANECA, Frei. Carta da Pítia a Damão, n.VII, Apud: MELLO, Evaldo Cabral de. (org.) Frei Joaquim do Amor Divino Caneca p.257-258. Grifo no original. 
unitarismo e Europa, simetricamente se associavam república, democracia, federalismo e América". ${ }^{43}$

Antonio Borges da Fonseca faria desta correlação uma rotina em seus periódicos. Na folha Abelha pernambucana, por exemplo, redige um pequeno histórico da Revolução Americana, seguido de comentários a respeito da Constituição, votada em 1787: "Neste ano é que uma convenção de todos os Estados, menos o de Rhode Island, teve lugar em Filadélfia, presidida pelo General Washington e se fixou a Constituição que ainda hoje rege". No mesmo exemplar, o redator paraibano divulgou encomiásticas biografias de George Washington e Benjamin Franklin, esta última repetida três meses depois, enaltecendo as virtudes patrióticas de ambos e os méritos intelectuais do segundo. ${ }^{44}$

No ano seguinte mais uma vez a Abelha cede lugar às considerações sobre "os povos" da América do Norte fazendo uso de sua sempre criativa linguagem:

De todos os povos livres conhecidos os Virjinios, nação da república federativa dos Estados Unidos da América, foram o primeiro (sic) que escreveu as verdades eternas e fundamentais da sociedade em suas leis e que fez proceder sua Constituição (...) de uma declaração dos direitos do homem em sociedade, como fundamental e regulador de suas leis e de sua polícia (...) cinco outros povos da mesma confederação: os Pensilvanios, Delawarres, Marilandos, Carolinos do Setentrional, e Masacusets (sic) seguiram o exemplo dos Virjinios e os Americanos ofereceram ao Terror das nações europeias, degradadas pela longa servidão, estas grandes Verdades Sociais (...). Pela primeira vez o homem e os povos conheceram uma religião pulítica (sic). ${ }^{45}$

O jornal Abelha pernambucana foi fundado em 1829 por Antonio Borges da Fonseca, possivelmente com a ajuda da sociedade secreta Jardineira ou Carpinteiros de São José, e circulou em Recife até 31 de agosto de 1830, quando o redator paraibano dirigiu-se ao Rio de Janeiro. Infelizmente há poucos dados sobre a associação, além do depoimento do próprio Borges, publicado em 1867.

Em 1828, tendo Pedro I criado a sociedade da coluna, para as províncias vieram presidentes adequados. Paraíba foi dada a Gabriel Getúlio Monteiro de Mendonça e Pernambuco a Tomaz Xavier Garcia de Almeida (...).

Por essa ocasião, estabeleceu-se na corte a sociedade secreta - Jardineira ou carpinteiros de S. Jose, para opor à sociedade coluna do Trono, cujo fim era o imperador absoluto, ou como se dizia então - o imperador sem trambolho.

43 STARLING, Heloísa Maria Murgel e LYNCH, Christian Edward Cyril. República/republicanos. In: FERES JÚNIOR João. (org.) Léxico da história dos conceitos políticos. Belo Horizonte: Editora UFMG, 2009, p.232. Grifo no original. 44 Abelha pernambucana, n.69, 15 de dezembro de 1829.

45 Abelha pernambucana, n.123, 25 de junho de 1830. Grifo no original. 
O grande centro criou centros nas capitais das províncias: fui lembrado em 1828 para um dos que deviam organizar a sociedade jardineira na Paraíba. ${ }^{46}$

Todavia, a despeito das observações de Borges da Fonseca quanto à fundação da sociedade na Corte em 1828, cinco anos antes frei Caneca informava sobre as atividades da Jardineira ou Keporótica em Pernambuco, assegurando que não obstante seus propagadores Ihe confiram uma "antiguidade religiosa e respeitável, data a sua existência de muito pouco tempo, e tem por pátria Coimbra ${ }^{47}$, sendo instituída para reformar a Maçonaria". ${ }^{48}$

Asseverava então o frade carmelita que a irmandade utilizava-se, à semelhança das confrarias maçônicas, de cerimônias destinadas à recepção dos seus adeptos e elevação dos sócios a diferentes graus e dignidades, servindo-se de

certos símbolos, alegóricos e significativos de virtudes morais e sociais. Os irmãos ou confrades se conhecem mutuamente por certos sinais e palavras, com que também dão a saber o seu estado de vexame e perseguição, para serem socorridos dos seus companheiros. O seu fim é unicamente o socorro da humanidade oprimida pelos revezes da cega fortuna, ou das injustiças da tirania, por meios que sejam compatíveis com a obediência às leis, e respeito às autoridades constituídas, sem jamais nada se importar com a consciência dos sócios relativamente ao modo de prestar obediência, acatamento e adoração ao supremo autor da natureza.

Contudo, não há registro preciso da instalação da Jardineira, seja na Corte ou em Pernambuco. Seguindo ainda as declarações de frei Caneca, esta teria ocorrido em Recife em 1821, "pouco mais ou menos (...) se plantou aqui o primeiro jardim, o qual se tem ramificado em outros muitos por toda a província, compreendendo em si pessoas de todas as classes, distintas por seu saber e probidade". ${ }^{49}$

Parece plausível que a sociedade secreta tenha subsidiado o jovem Borges da Fonseca no empreendimento de seu primeiro jornal, a Gazeta paraibana em 1828. No entanto, apesar da popularidade que o periódico Ihe confere, no ano seguinte o redator viria a ser detido, acusado de "abuso de liberdade de imprensa". Por este motivo, teria também sido demitido da escola em que lecionava como "professor de primeiras letras" na Cidade

46 FONSECA, Antonio Borges da. Manifesto político: apontamentos de minha vida politica e da vida politica do Dr. Urbano Sabino Pessoa de Melo. Recife: Typographia Commercial de G. H. de Mira, 1867, p.6. Grifo no original.

47 Moreira de Azevedo afirma ter sido criada a sociedade política dos Jardineiros ou Keporótica por Francisco Gê Acaiaba de Montezuma, futuro Visconde de Jequitinhonha, em Coimbra "com o fim ostensivo de promover e sustentar a liberdade do povo português. Chegando à província da Bahia em 18 de setembro de 1821, criou a Sociedade dos Jardineiros". AZEVEDO, Manuel Duarte Moreira de. Sociedades Fundadas no Brasyl desde os Tempos Coloniais até o Começo do Actual Reinado. Revista Trimensal do Intituto Histórico, Geographico e Ethnographico do Brasil. Rio de Janeiro, t.XLVIII, parte 2, p.280, 1885.

48 Carta de Pítia a Damão, n.IX. Apud: MELLO, Evaldo Cabral de. (org.) Frei Joaquim do Amor Divino Caneca, p.275. Grifo no original.

49 Carta de Pítia a Damão, n.IX. Apud: MELLO, Evaldo Cabral de. (org.) Frei Joaquim do Amor Divino Caneca, p.276. 
Alta, expulso da Paraíba e sido aprisionado na Fortaleza das Cinco Pontas em Recife.

A detenção teria sido motivada, segundo a reconstrução do episódio elaborada pelo autor 38 anos depois, pela "guerra de morte" incitada pela folha ao "partido português" e aos colunas. Entretanto no mês seguinte, em março, Borges da Fonseca foi absolvido "por decisão do conselho de jurados que não achou matéria para acusação". ${ }^{50}$ Mais uma vez a Jardineira viria em auxílio do jovem redator nomeando-o para o diretório da congregação em Recife.

No mês seguinte, provavelmente tendo por fim combater as idéias propaladas pela sociedade Coluna do trono e do altar, Borges da Fonseca funda a folha Abelha pernambucana que começa a circular no dia 24 de abril de 1829.

Deve-se notar a originalidade da ortografia, própria dos periódicos redigidos por Borges da Fonseca. ${ }^{51} \mathrm{O}$ redator pouco se referiu a esta particularidade além da conhecida observação no primeiro número de $O$ republico, em outubro de 1830, quando participa não mais pretender seguir o que denominava de "ortografia filosófica ou da pronunciação" conforme havia feito anteriormente.

Com efeito, ao qualificar a escrita como "de pronunciação", pretendia adotar uma redação referenciada pela ortografia fonética ou sônica com características marcadamente regionais. Parece razoável que ao ser transferido para o Rio de Janeiro, esta forma ortográfica perdesse o sentido, ainda que em menor medida fosse mantida nos artigos de O republico, tanto entre 1830 e 1831, na fase fluminense, quanto no ano seguinte, de maneira ainda mais acentuada, quando o jornal passa a ser editado na Paraíba.

Talvez seja lícito supor que a particular ortografia dos periódicos não expresse qualquer excentricidade do redator, como afirmavam seus adversários, mas sim que se inscreva no projeto político mais amplo em prol do federalismo, compreendido também como a afirmação das peculiaridades locais, assimilando-se assim as formas de expressão oral e escrita.

Além disso, parece muito provável que a ênfase na pronúncia regional guardasse relação com o ascendência que exercera Cipriano Barata sobre Borges da Fonseca. ${ }^{52}$ Tal influência teria, portanto, movido este a aplicar à ortografia a simbologia política da qual aquele se valera ao longo de sua

50 Antonio Borges da Fonseca. Manifesto político, p.7.

51 Sobre Borges da Fonseca, ver Ricci, Maria Lúcia de Souza Rangel. A atuação política de um publicista: Antonio Borges da Fonseca. Campinas: Pontifícia Universidade de Campinas, 1995.

52 "Antonio Borges da Fonseca (...) seria um dos continuadores da linhagem e estilo político de Cipriano, participando, já depois da morte deste, da Revolta Praieira de 1848. Ao deixar a Corte e voltar para a Bahia, em 1830, Cipriano escolheu $O$ repúblico (...) para veicular seus agradecimentos aos que o tinham visitado e com ele se solidarizado após sete anos de cárcere. Posteriormente, através do mesmo jornal, Borges da Fonseca lançaria a candidatura de Cipriano Barata ao Senado". MOREL, Marco. Cipriano Barata na Sentinela da Liberdade. Salvador: Academia de Letras da Bahia; Assembleia Legislativa do Estado da Bahia, 2001, p.246-247. 
vida. Como se sabe, o redator baiano notabilizara-se pelo uso de roupas manufaturadas com o algodão da terra, assim como pela adoção do chapéu de palha de taquaruçú, insígnias que representariam a defesa da "causa patriótica".

Para além da ortografia do jornal, a memória política de Pernambuco determinaria formas diversas de construção do passado ou o enaltecimento de lideranças que encarnavam os conflitos do presente. No dia 16 de junho de 1829 a Abelha pernambucana proclamava:

Quantas vezes não temos nós visto o perverso opressor da humanidade, o carrasco do gênero humano ser canonizado e vilipendiado o cidadão virtuoso e probo? (...) Periódicos vendidos não enchem de opróbrios o Incomparável, o Virtuoso, o Herói BARATA? O nunca assaz chorado o Imortal CANECA, que nele perdeu Pernambuco e o Brasil todo um Herói, um sábio não tem sido menosprezado? O Virtuoso AGOSTINHO (digam suas virtudes os negociantes do Recife) não tem sido infamemente boquejado? ${ }^{53}$

Tais assertivas valeriam a Borges da Fonseca mais um processo, instaurado no mês seguinte, a partir de denúncia apresentada pelo Promotor do Júri ao Juiz de Direito "contra a nossa Abelha $n^{\circ} 16$ (...). como pois entendeu o Sr Promotor compreender essa Lei a parte do que escrevemos nesse $\mathrm{n}^{\circ}$ denunciado relativamente a Barata, Fr Caneca e Agostinho? (...) Seria crime chamá-los Heróis e Virtuosos?". ${ }^{54}$

Em dezembro, edita a Abelha Pernambucana um longo texto em defesa da Constituição norte-americana, votada em 1787, "embalados desde esta feliz época em princípios de Liberdade, a mais bem entendida, florescem (...) e hoje se acham no auge da prosperidade", seguido de extratos biográficos de George Washington e Benjamin Franklin. ${ }^{55}$ A referência ao paradigma da revolução norte-americana seria a tônica do periódico ao longo do ano de 1830 até seu fechamento em agosto.

Em outubro de 1830 Borges da Fonseca inicia a publicação de O republico no Rio de Janeiro, argumentando em favor das províncias do "norte".

Se continua Pernambuco a ser flagelado, deixará ele de se declarar contra o governo do Rio de Janeiro? (...)

53 Abelha pernambucana, n.16, 2 de junho de 1829. Destaque no original. Segundo narrativa anônima, por ocasião da Confederação do Equador, em 23 de julho de 1824, o Major Emiliano Benício Mundurucu e seu regimento pretendiam assaltar as casas de comerciantes portugueses, mas foram impedidos por Agostinho Bezerra Cavalcante, Capitão do Regimento de Henriques: "Agostinho Bezerra, sabedor da intenção de Emiliano por também ter sido para isso convidado, marchou com o seu regimento de Henriques e formando-se em frente do de Emiliano, declarou que não era ladrão nem assassino, nem consentia que se praticasse tal infâmia". Cf: Rio de Janeiro. Divisão de Manuscritos da Biblioteca Nacional. Histórico dos fatos ocorridos em Pernambuco durante a revolução de 1824. Agostinho Bezerra foi enforcado em 19 de março de 1825.

Abelha pernambucana, n.69, 18 de dezembro de 1829. 
Se o governo quer que as províncias estejam unidas deve tratá-las bem porque o governo não deve ignorar que o espírito nacional do Brasil é federativo, espírito formado pelos déspotas de portugal por sua conveniência .(...) A natureza nos criou para vivermos federados e só a sabedoria de um governo nacional nos poderá conservar unidos. ${ }^{56}$

Após o 7 de abril, Borges da Fonseca, que seria em breve enviado à Paraíba, possivelmente para neutralizar a influência que passara a ter na Corte em virtude de sua participação nos episódios que precederam a Abdicação, escreveria mais um artigo afirmando a incompatibilidade entre os princípios monárquicos e a América.

E nem cause medo o falar-se contra a estabilidade dos princípios monárquicos na América; eles são incompatíveis com a nossa posição geográfica (...) os homens verdadeiramente francos, verdadeiramente americanos concordarão de boa mente comigo: (...). Como verdadeiro amigo da América, eu não posso ter outros desejos que não sejam os da ordem (...), fugir da realeza, fugir da demagogia são os princípios que sempre professei. ${ }^{57}$

\section{A República de afogados: a última cabeça da hidra revolucionária de Pernambuco}

Assim se referia o então presidente de Pernambuco, Thomaz Xavier Garcia de Almeida, à revolta iniciada na Vila de Santo Antão em fevereiro de 1829. O temor das autoridades de que outro movimento republicano se articulasse na província não cessara mesmo após o massacre perpetrado pela Comissão Militar instalada entre 1824 e 1825.

No dia 2 de fevereiro de 1829, dois movimentos, provavelmente articulados e praticamente simultâneos, ocuparam as páginas dos jornais. 0 primeiro teve início quando

um grupo de perversos (...) tiveram (sic) a criminosa audácia de marchar dos Afogados, arrabalde desta Cidade e, passando pela Várzea e Jaboatão, declaravam que iam à Vila de Santo Antão a instalar um Governo Republicano: uniram-se-lhes ali alguns desgraçados, como eles bandidos e sem nome e, com efeito chegados em n. de 80 a Santo Antão (...) procuravam formalizar o seu cerebrino Governo. ${ }^{58}$

Para tanto, depuseram as autoridades locais, apoderaram-se das armas do quartel e invadiram a cadeia pública libertando os presos. No

\footnotetext{
O republico, n.7, 23 de outubro de 1830 .

O republico, n.67, 19 de maio de 1831

58 Divisão de manuscritos da Biblioteca Nacional. Ofício do Desembargador Ouvidor Geral do Crime da Relação Gustavo Adolfo de Aguiar ao Ministro da Justiça Lucio Soares Teixeira de Gouvea, 7 de fevereiro de 1829. Cf.
} 
dia seguinte, pretenderam reunir a Câmara no intuito de nomear um novo governo. Ao que tudo indica, a revolta contou com o apoio e participação de libertos e até mesmo de escravos, em virtude da divulgação de boatos que asseguravam que com a iminência da "abolição do tráfico da escravatura, tornariam à escravidão todos os homens de cor libertos, o que concorreu para haver uma quase comoção na freguesia de Ipojuca".

O mesmo ofício garantia que agentes do governo nos Estados Unidos e Inglaterra advertiam que em direção à província se dispunham a partir "alguns dos principais cabeças da revolução de 1824 que haviam sido banidos e sentenciados à morte"; afiançava também que "papéis incendiários (...) se afixaram na [província] do Maranhão, apontando-se o distrito de Pastos Bons como o lugar onde deveria ser proclamado o sistema republicano". 59

Em ofício de 12 de março de 1829, Lúcio Soares notifica o Presidente da província que a rebelião já havia sido sufocada e a tropa recolhida a seus quartéis "à exceção de um destacamento de vinte homens que mandei ficar na Povoação do Brejo [da Madre de Deus] para o fim de auxiliar a pesquisa e efetiva apreensão dos cabeças da revolta que se julga estarem ali mesmo agasalhados, bem como alguns dos banidos pela Comissão Militar de 1824, que se diz haverem regressado e estariam naquele sertão". ${ }^{60}$

Ao participar a dispersão dos revoltosos ao ministro da Justiça, o ouvidor do Crime Gustavo Adolfo de Aguilar procurou minimizar o episódio, chamando-o de "comédia republicana". Assegurava que embora os revoltosos continuassem a marcha para o sertão no termo de Cimbres, em direção à fazenda do Jatobá, teriam sido

desamparados por alguns outros dos sócios; escalaram o tronco da povoação (...), tiraram ao Comandante do lugar doze espingardas Nacionais (...) e finalmente em o dia 9 pela manhã foram depois dispersos poucas léguas adiante daquela Povoação por [ileg.] de Ordenanças e perseguidos pela tropa regular mandada pelo Governo, alguns foram presos, o resto fugiu em debandada, deixando no mato armas, cartuchame e outros gêneros de guerra. Terminada assim a Comédia Republicana, remeteu o Ex ${ }^{m o}$ Presidente da Província ao Ex ${ }^{m o}$ Governador os documentos originais acerca da referida Rebelião. ${ }^{61}$

Todavia, a "comédia republicana" chamou a atenção do Conselho de Estado que aprovou na 24a sessão de 26 de fevereiro de 1829 a "suspensão das formalidades que garantem a liberdade individual naquela Província para serem presos e tratados como rebeldes os que nela se achassem

Acontecimentos em Pernambuco para inaugurar uma republica, 1829

59 Ofício de Lúcio Soares Teixeira de Gouveia a Joaquim Marcelino de Brito, 5 de maio de 1829. Citado por COSTA, Francisco Augusto Pereira da. Anais pernambucanos. Recife, v.IX, p.306-307, 1965.

60 Divisão de manuscritos da Biblioteca Nacional. Acontecimentos em Pernambuco para inaugurar uma republica, 1829.

61 Divisão de manuscritos da Biblioteca Nacional. Ofício de Gustavo Adolfo de Aguilar sobre a rebelião republicana ocorrida em Pernambuco. Recife, 30 de março de 1829. 
implicados". ${ }^{62}$ Efetivamente, no dia seguinte, o imperador emitiu decreto anuindo à sugestão do Conselho de Estado.

\begin{abstract}
Tendo aparecido na Província de Pernambuco uma rebelião de facciosos contra a forma de Governo Monárquico-Constitucional, estabelecido e jurado neste Império, e pedindo a segurança do Estado que se dispensem por tempo determinado as formalidades que garantem a liberdade individual. Hei, por bem, tendo ouvido o Meu Conselho de Estado e na conformidade do artigo cento setenta e nove, parágrafo trinta e cinco da Constituição, suspender provisoriamente na mesma Província as referidas formalidades, a fim de que se possa proceder sem elas contra quaisquer indivíduos complicados naquela rebelião até que cesse a necessidade urgente desta medida (...).

Palácio do Rio de Janeiro, em 27 de Fevereiro de mil oitocentos e vinte nove, oitavo da independência do Império. ${ }^{63}$
\end{abstract}

O segundo movimento, da mesma sorte iniciado no dia 2 de fevereiro e associado pelas autoridades à revolta da vila de Santo Antão, restringira-se, ao que parece, à cidade do Recife. Conforme o relato dos ofícios redigidos pela Ouvidoria do Crime, "no dia 2 amanheceram pregados nas esquinas das ruas da Cidade vários Pasquins ${ }^{64}$ sediciosos, concitando o Povo à rebelião, que continuaram a aparecer nos três dias subseqüentes" ${ }^{65}$ Imediatamente foi realizada a "ata Judicial de achada" e aberta uma devassa, amparada no Aviso de 20 de setembro do ano anterior que previa restrições à liberdade de imprensa.

Em menos de dois meses, a devassa dos pasquins já havia sido concluída, mas, ao contrário da revolta iniciada em Afogados, na qual teria sido envolvida a população pobre da periferia, naquela foram implicados o fundador do Diario de Pernambuco, Antonino Joze de Miranda Falcão, os ex-colaboradores de Paes de Andrade em 1824, Antonio Elias de Moraes e Joze Tavares Gomes da Fonseca, o fiscal de posturas do bairro de Santo Antonio e sobrinho de Cipriano Barata, Rodolfo João Barata, Antonio Joaquim de Mello, Francisco Xavier Pereira de Oliveira, Francisco Joze de Veraz e Joze Machado Freire. ${ }^{66}$

Na opinião de Marcus Carvalho, em que pese a retórica republicana, a "República dos afogados" e a panfletagem que se seguiu na cidade tinham por objetivo primordial influenciar o resultado das eleições para vereadores e deputados provinciais, além de refletir o conflito jurisdicional entre os capitães-mores e os juízes de paz. O autor lembra que o processo

62 Atas do Conselho de Estado. Brasília: Gráfica do Senado Federal, 1973, v.2, p.67-69.

63 Divisão de manuscritos da Biblioteca Nacional. Decreto Imperial suspendendo, provisoriamente, na província de Pernambuco as formalidades que garantem a liberdade individual.

64 A palavra pasquim também significava à época "sátira por escrito pregada nas ruas ou portas".

65 Ofício do Desembargador Ouvidor Geral do Crime da Relação Gustavo Adolfo de Aguilar ao Ministro da Justiça Lucio Soares Teixeira de Gouvea, 7 de fevereiro de 1829.

66 Divisão de Manuscritos da Biblioteca Nacional.Relação dos Reus pronunciados na Devassa dos Pasquins que se acham presos. 
eleitoral comprovara o prestígio dos ex-participantes da Confederação do Equador, pois, mesmo estando presos, teriam sido eleitos para a Câmara Municipal Antonio Elias de Moraes e Antonio Joaquim de Mello, sendo este o segundo candidato mais votado. ${ }^{67}$

No entanto, a constante alusão dos jornais, ao longo do ano de 1829, à República de Vitória de Santo Antão e principalmente à devassa dos pasquins evidenciava a centralidade do papel da imprensa no processo de resguardar a memória da Confederação do Equador, compreendida por muitos como a legítima reação da província ao "despotismo" do imperador.

\section{A Sociedade Federal de Pernambuco}

A reelaboração do discurso republicano na província também pode ser observada por meio da leitura dos jornais que divulgaram tanto a criação quanto as atas das sessões da Sociedade Federal de Pernambuco. Fundada em 16 de outubro de 1831 no consistório da igreja de Nossa Senhora da Conceição dos Militares em Recife, tal associação reuniria boa parte dos indivíduos comprometidos com os movimentos políticos decorridos na década anterior.

A difusão de suas atividades ficou a cargo dos jornais Diario de Pernambuco, Bussola da liberdade e da folha O federalista, porta-voz da associação.

Cumpre lembrar que assumir publicamente através de artigos na imprensa a defesa da república como forma de governo era considerado crime previsto tanto pelo Código Criminal de 1830, quanto pelo Código de Processo de 1832, além de ser inconstitucional. Por essa razão, nos primeiros anos da Regência, as propostas de reforma na Constituição permitiram entrever, em grande medida, na reflexão em torno das formas de governo, bem como na resignificação dos conceitos políticos, disputas entre diversos grupos e projetos, mas igualmente a herança de um ideário republicano, permeado pelos princípios da llustração, que se manifestava mediante diversos recursos, entre os quais a apologia de governos eletivos, como também a depreciação dos atributos e liturgia próprios da monarquia.

O jornal Bussola da liberdade, redigido pelo padre João Barboza Cordeiro, ativo participante do movimento político de 1817 no Rio Grande do Norte, como também da Confederação do Equador, publicava extensos artigos em favor da federação, além de discorrer a respeito das diferentes experiências históricas de associações entre monarquias e repúblicas.

Por outro lado, ao refletir sobre as formas de governo, $O$ federalista asseverava que a Federação é o governo que mais se aproxima da "Democracia", através da qual é possível livrar-se dos "inconvenientes da

67 CARVALHO, Marcus J. M. de. Aí vem o Capitão-Mor: as eleições de 1828-30 e a questão do poder local no Brasil imperial. Tempo, Rio de Janeiro, vol.7, n.13, p.175 e 177, 2002. 
Aristocracia e Monarquia". Detém-se então o redator em considerações a respeito dos governos aristocráticos e monárquicos:
A Aristocracia é a forma de Governo em que o Império civil está depositado nas mãos de um certo número de Cidadãos chamados nobres. Esta forma de Governo oferece um monstruoso complexo de males: (...) Nesta forma de governo mingua-se a Liberdade, paralisa-se a Indústria (...) detestam-se as virtudes morais e civis dos Cidadãos da ordem inferior, que é reputada como um nada e só destinada para obedecer (...). Ainda aqui não findam os males (...) ainda nos restam os que provêem do Go- verno da Monarquia (...).
Esta forma de Governo sempre pende naturalmente para o despotismo (...) Ainda que o Rei seja justo, se ele ouvir unicamente a linguagem da escravidão, os discursos dos aduladores que o rodeiam, ele inocentemente causa a ruína e o descontentamento. ${ }^{68}$

Todavia, os argumentos em prol da federação nunca apoiavam-se na tradição ou na História, mas sim na construção de uma ideia de natureza indômita que assinalaria a especificidade do continente americano, marcado pelo gigantismo da extensão territorial, por rios caudalosos, pelas serranias "intransitáveis" e desertos "intransponíveis", elementos que seriam agravados pela escassez e diversidade dos habitantes:
Cada uma das províncias, ainda das mais pequenas, tem maior extensão do que Reinos inteiros da Europa.
A natureza as dividiu por montanhas, lagos, rios e serranias, de sorte que al- gumas subsistem sem relação alguma com as outras, sem saberem, nem se importarem do que passa fora do seu país: nos mesmos usos e costumes há uma diferença espantosa. O Paraense v. g. e o mineiro não parecem pertencer à mesma Nação, senão em falarem a mesma Língua, se bem que até nisto têm um acento de pronúncia muito diverso. ${ }^{69}$

Não obstante, a relação entre federação e república, estabelecida no jornal da Sociedade, por vezes comportava a ideia de que a primeira seria capaz de engendrar as virtudes políticas necessárias à implementação da segunda. Por esse motivo, foram impressos artigos pedagógicos que visavam persuadir seus leitores da necessidade de aprovação de reformas, tendo em vista eliminar paulatinamente os princípios monárquicos na América. O federalista, em seu terceiro número, retoma os freqüentes argumentos em defesa da federação, afiançando que a "marcha republicana" é irreversível.

O Homem que reflete seriamente sobre o vastíssimo Brasil, que considera a sua inteira separação da Europa, sua posição, sua capacidade territorial, seus

68 O federalista, n.4, 28 de janeiro de 1832.

69 O federalista, n.2, 13 de janeiro de 1832. 
imensos recursos, suas Províncias tão distantes umas das outras, e sobretudo a natureza dos Estados que o cercam; não pode desconhecer que o Brasil há de vir a ser Republicano. (...)

É preciso ser cego para não ver que o nosso Brasil não pode conservar uma Monarquia encravada no meio de Repúblicas, sem que haja no continente Americano um só Estado que se interesse por ela, e sim que a deseje ver quanto antes aniquilada; por isso que enquanto esses Estados virem por cá uma testa coroada, terão sempre justas desconfianças de que o sistema Europeu prepondere em o Novo Mundo. Por outra parte é engano pensar que os Brasileiros são tão aterrados à Monarquia como os velhos Povos da Europa. Nós nunca vimos por cá o trono, com todas as suas ilusões, senão há poucos anos. ${ }^{70}$

\section{Conclusão}

Pelo que foi exposto, no que concerne à ideia de república nas primeiras décadas do Império do Brasil, notadamente em Pernambuco, agregou-se a este conceito uma perspectiva de tempo linear que, embora não fosse exclusiva naquele contexto, não mais comportaria a tradição do equilíbrio institucional das forças políticas, mas seria remetida ao futuro, ou nos termos de Koselleck, transformar-se-ia num conceito de movimento.

Semelhante percepção temporal adquirira contornos definidos pelo claro e reiterado sentimento de ruptura com o passado, constantemente designado por "três séculos de escravidão". Todavia, tal distinção parece ter se revestido historicamente de uma dimensão não apenas temporal mas também espacial, identificando-se na América a fórmula de sobrevivência das repúblicas no tempo, a partir do deslocamento semântico dos conceitos constitutivos do secular ideário republicano.

Assim a "América", reunindo num conceito a um só tempo uma peculiar ideia de natureza e uma singular experiência histórica, delinearia tanto os desígnios políticos do país quanto a compreensão dos conceitos, referidos a um "novo" espaço de experiência. Por essa razão, parece possível afirmar que as reflexões e reivindicações relativas à república federativa fundamentaram o ideário republicano, em vista da precedência conferida à geografia, ou seja, à localização do Brasil na América, particularizada pela especificidade do continente americano, concepção esta legatária da polêmica sobre o Novo Mundo.

Talvez seja possível afirmar que os desdobramentos políticos desta célebre controvérsia tenham sido subestimados pela historiografia, de vez que, à contraposição entre "sistema europeu" e "sistema americano", correspondiam tanto a disparidade entre dois tempos históricos quanto o antagonismo entre repúblicas e monarquias.

70 O federalista, n.3, 17 de janeiro de 1832 
Como se pode notar, a ponderação centrava-se basicamente em três temas: em primeiro lugar, o que seria entendido como "imposição geográfica" ou a "localidade entre governos republicanos", princípio este que, desdobrando-se na suposta "afinidade de condições" entre as ex-colônias americanas, determinaria a qualificação da monarquia no Brasil como uma "anomalia"; em segundo lugar a recorrente menção à ausência de aristocracia hereditária ou "artificial" na América; em terceiro lugar a alegação de que as reformas federais seriam vistas como um caminho para a república, infundindo nos indivíduos as virtudes cívicas julgadas necessárias a esta forma de governo.

A linguagem republicana inscreve-se, portanto, nessa circunstância, não apenas na distância entre dois continentes mas, essencialmente, entre dois tempos - o velho e o novo - o decadente, impregnado de vícios, desigualdades, perseguições e hierarquias, voltado para o passado; e o que seria idealizado como promissor, eivado de liberdade, representatividade e igualdade legal, apontando para o futuro. 